\title{
Mobility Memories and Space: Mesolithic Living Close to the Ancylus Lake in Eastern Middle Sweden, $8000-6000$ cal BC
}

\author{
Tom Carlsson
}

Foundation Cultural Heritage, Sweden

Copyright $(2017$ by authors, all rights reserved. Authors agree that this article remains permanently open access under the terms of the Creative Commons Attribution License 4.0 International License

\begin{abstract}
This paper has its focus on an area in eastern middle Sweden, $8000-6000$ BC. It has the intention to presents several Mesolithic settlement sites situated within close to each other. Since several of the settlement sites includes remains of houses, preserved burnt animal bones and macrofossils the sites are fairly unique for the region. Radiocarbon dating illustrates that people stayed in the area and often used the very same places for more than 2000 years even though substantial changes in the composition of the landscape occurred. Despite an initial nearness to the ancient shores of the Baltic Sea, the Ancylus Lake, animal bones and macrofossils indicate an economical continuity of hunting and gathering in the woods. In Mesolithic research mobility is an axiom. Is the idea of mobility of small social groups between special purpose places in the inland and large coastal settlements still plausible, in the decade after 2010, as a general interpretative model? "Laboratory Archaeology": a DNA and a variation of Isotope analysis from different Mesolithic sites highlight a rather disparate picture for Mesolithic living in Europe. As any other truisms, mobility must constantly be discussed and reassessed. Unfortunately, because of bad preservation for organic material, apart from burnt and charcoal no further Isotope analysis where possible for the sites presented in the paper. But, even without any evidence from Isotopes analysis we must evaluate and consider other options than the standard model for mobility. In the paper I try to search for theoretical concept for place and landscape and I use Heidegger's concept of "dwelling" [19] to understand how Mesolithic man, in this area, established an economical/social relations to a set of places, locations, in the landscape. Places were more than a base for subsistence, increasingly appearing as 'places for the presence of the past, memories'. Peopled recreated that relationship by using places for every-day activities over and over again.
\end{abstract}

Keywords Mesolithic, Sweden, Environment, Settlements, Houses, Mobility, Sedentary, Memories

\section{Introduction}

The point of departure for the paper is the recently excavated Mesolithic settlement sites in the Östergötland district, eastern Middle Sweden (fig. 1 and 2), established near the shores of the Ancylus Lake some $10000-8000$ years ago (fig 3 ). Within a distance of 15 kilometers, several settlement sites occur. Some of them with traces of dwellings, hearths, pits, artefacts and splinters of quartz and flint, burnt animal bones, charcoal and macrofossils. Since flint doesn't occur naturally in the ground in this area all these lithic are brought by man. The chronology of the settlement sites is similar, with an establishment phase at around $8500-7500$ cal BC, followed by almost continual settlement until around $6000 \mathrm{cal}$ BC, after which the settlements were abandoned. People stayed in the same area, even on the same sites, for thousands of years, despite the transformation of the appearance and composition of the landscape due to the elevation of the land and the drainage of the Ancylus Lake, along with the impact of climate changes on animals and nature. There are several contemporary settlement sites in the research area, $30-60$ kilometers from Ancylus Lake, i.e. the ancient coast of the Baltic Sea, like Högby, Holmen, Storlyckan, Motala and many others. Animal bones found at inland settlement sites also indicate that red deer, elk and beaver were hunted, along with the gathering of hazelnuts $[10,5,6,9,28,24,20,32]$. According to the most general and widely accepted model [3]: local groups of hunters and gatherers in Europe during the Boreal and Atlantic climatic period maximized their economy through seasonal mobility between sites with different ecological conditions. Small family groups or bands, migrated to the inland during the summer, and in the wintertime people assembled into larger social groups along the coast. A common explanation for mobility is that it is a result of economic incentives, only. In archaeology research, Mesolithic economy is often regarded as highly pragmatic and adapted to the environment.

However, in this paper, subsistence and diet is linked with the strategies of the local society in their choices and the 
selections they made among the available range. Diet is identity; food is memories. This idea is supported by "Laboratory Archaeology". Today, when a greater number of strontium and isotope analyses on human remains are performed throughout Europe we can see the indications that Mesolithic societies had considerably more varied and complex economic strategies than any model could have predicted. There is a difference in diet between local communities, different age groups, as well as between individuals $[13,16,36,15,26]$. The results raise a string of questions. In this present day, does the idea of mobility between small inland sites and large coastal settlements still work as a general model for interpretation? And if not, then we need a concept of landscape and utilizing places in a long term of changing environment.

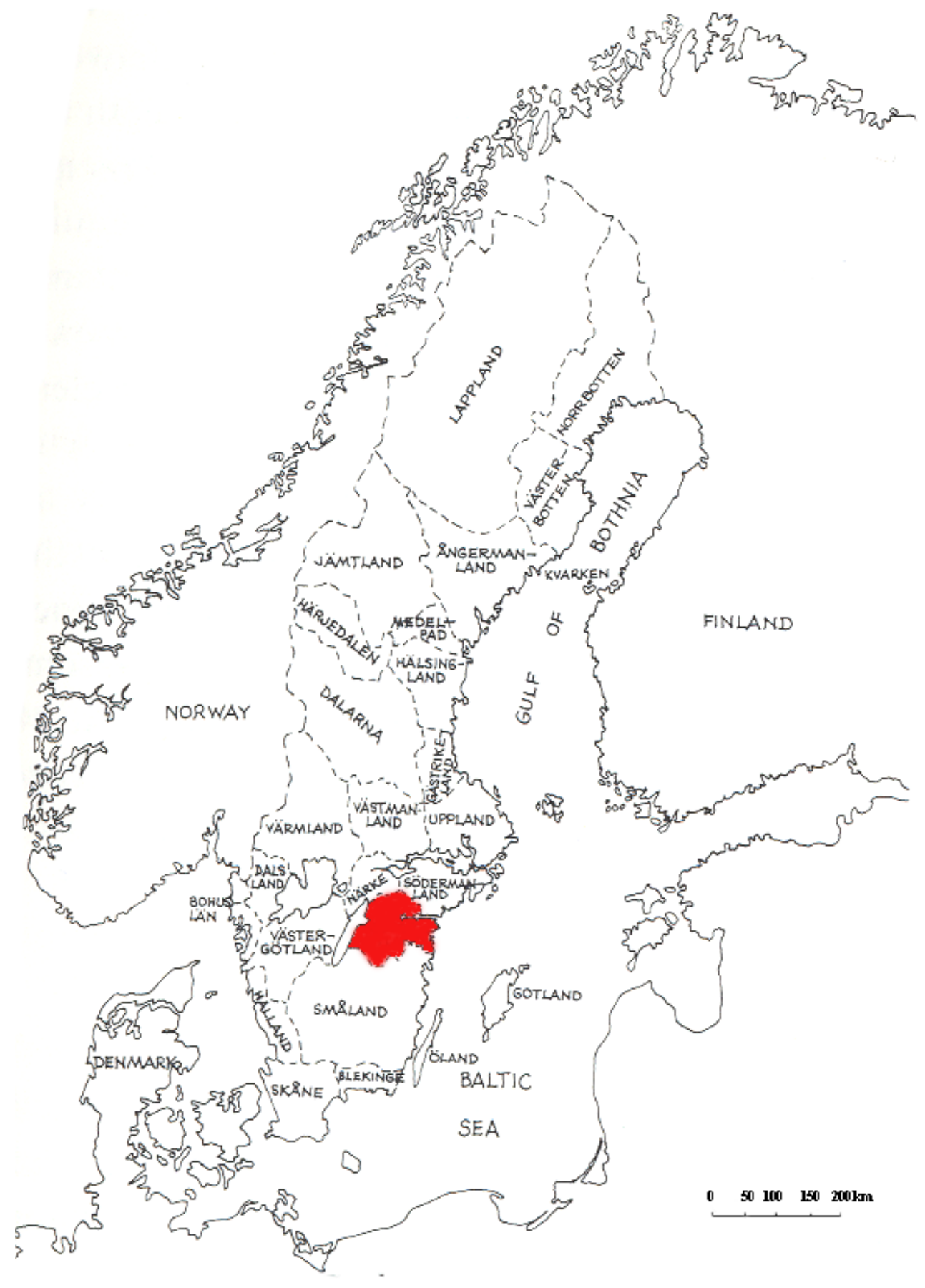

Figure 1. Scandinavia and the location of the Östergötland province 


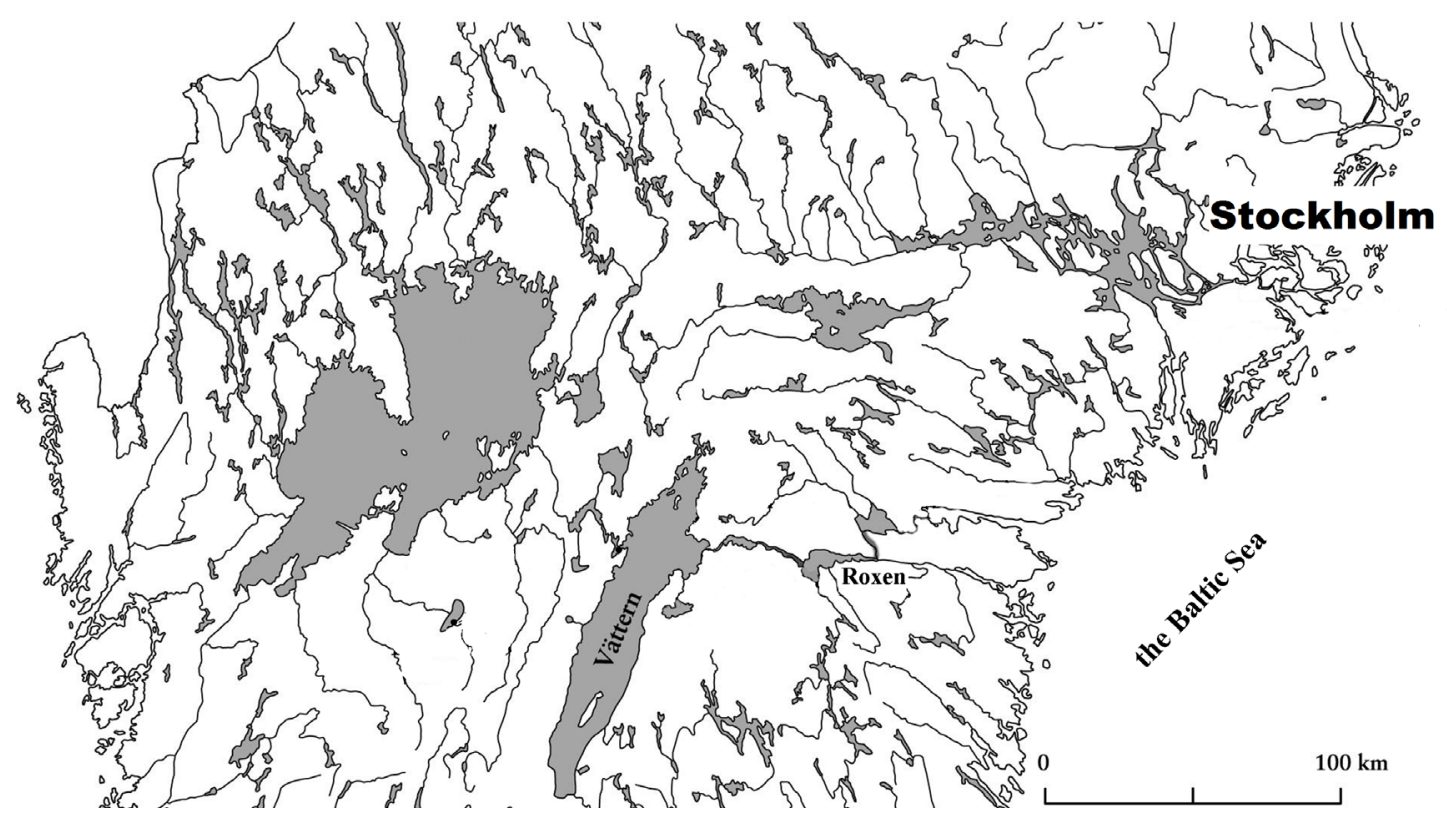

Figure 2. Present day research area.

\section{Theoretical Point of Departure - Mobility, Space and Memories}

'We make two assumptions about hunter and gatherers: (1) they live in small groups, and (2) they move around a lot' Richard B Lees \& Irven De Vore [27] and their anthropological model together with Lewis Binford's adaptive model [3] have been highly influential in Mesolithic research all over Europe. Within Scandinavian research, mobility has even been regarded as the essence of hunter-gatherers, contrary to the sedentary life of farmers and cattle herders. The idea of mobility has been accompanied by descriptions of Mesolithic society as small-scale with social equality, characterized by egalitarianism and sexual equality [22, 43]. This has been criticized by Strassbourg [42] Carlsson [6] Karsten \& Knarrström [21]; Wickham-Jones [47] among others.

Problems arise when mobility is taken for granted and regarded as unproblematic [47], which becomes obvious when results from multi-isotope analyses of Mesolithic bones from various parts of Europe are made accessible. Diets and mobility may differ between two local groups even though the remains of material culture appear to be similar within a region. Two examples of this are Sado in Portugal [16] and Motala in Sweden [13]. Human bones from two sites in the Sado Valley in the south of Portugal were analyzed. The distance between these burials was 15 kilometers. Substantial series of radiocarbon dates indicate that both sites were quite regularly occupied for a period of 2000 years $(6500-4500$ cal BC). Nonetheless, isotope analyses show that both local groups had different hunting strategies during this period. Consequently, they would probably also have had different group identities. Despite living close to the sea, the one group lived mainly on terrestrially based food, while the other group showed clear signs of a marine diet [16]. Newly performed analyses from a site at Motala, in the Östergötland province, in eastern Middle Sweden, exemplify the complexity of mobility further. Bones from burials and from a sacrificial deposition have been analyzed. These human remains were all approximately contemporaneous (6500 - 4800 cal BC), discovered within only a few hundred meters from each other. Levels of strontium indicate that the buried individuals were born, and lived their lives, within a limited area. However, the amounts of ${ }^{13} \mathrm{C}$ distinctly reveal the consumption of marine fish; the distance to the Baltic Sea (the Litorina Sea) was 30 kilometers. The individuals from the other group, skulls and separate bones, came from more distant areas. Nevertheless, their diet seems to have been similar to the buried individuals. Isotope analyses (eight individuals of nine) showed a low degree of mobility during childhood; in adulthood, mobility and consequently diet changed. At least two individuals had distinct changes of diet during their teens, which most likely means that they moved to another place of abode [13].

Measurements of strontium, carbon and nitrogen isotope levels in Mesolithic skeletons show that mobility is not a clear-cut matter; we need an active view of spatiality. As a part of postmodern analysis of modern Western thinking, in line with for example feministic theory, scholars have pointed to fluid variations in constructions and experiences of space, and distantiation from universal values [37, 4]. The British geographers Mike Crang \& Nigel Thrift [11] states that 'space is practiced places'. This is the import of what Julian Thomas [45] terms space as 'a spatial story', which is a network of components of activity that are assembled into a weave of events and activities. The world does not primarily consist of universal raw data onto which we add secondary meaningfulness; the world is constituted of experiences, networks of experienced memories and information that has been learnt. We feel at home through our senses, not by continually analyzing the world around us. 
We hear birds singing, we smell smoke, we see sunlight [44]. In this sense, memories of experiences are like a route, a channel through with we create our interaction with our surroundings and other people. According to Sutton [44] memory is our sixth sense. Martin Heidegger [19] has made an important point for the understanding of locations/sites in that relations to places are shaped through dwelling: you make yourself at home by shaping your world, your surroundings; a relation to a place is created in the doing of ordinary things. When people make intentional lasting changes to a place, an important transformation occurs, a rearrangement of the place; it becomes the site for something. This is a visible manifestation of the connection between humans and their world. In accordance with these statements, space/a place is given a meaning of 'the presence of the past, memories. The French philosopher Henri Bergson [2] suggested that "There is no perception that is not full of memories". Memories are always collective in the sense that when we remember, our memories are stimulated by the social environment and by the people, things and constitutions that shaped them. In itself, the act of remembering is usually a collective process enabled by recurrent experiences and events in a place and with things with which we interact [17].

\section{Living by the Sea - Mesolithic Settlements Close to the Ancylus Lake}

The accumulation of knowledge about the Mesolithic in Östergötland is typical of Stone Age research in eastern Middle Sweden as a whole. Unfortunately the sites includes a very different quantity and quality of data. This is caused by bad preservation for organic material, only burnt bones, burnt macrofossils and charcoal are preserved. Since all excavations are conducted by Contract Archaeology also the size of the area for excavations as well as the financial resources for analysis has set the limit. Below, only the best-preserved sites will be closely presented as a basis for discussions, Stora Sjögestad, Kränge and Trädgårdstorp (fig 3). No human skeletons or scattered human bones has been found and, so far I know, it is not possible to perform Isotope analysis on burnt organic material, except for ${ }^{14} \mathrm{C}$, so no other Isotope analysis has been made.

Apart from the three described sites, a further seven excavated sites with similar dating occur in the region. The locations for these sites are shown in fig. 3 and only shortly presented below in the text and in table 4 . Within the studied area, more than 60 radiocarbon dates have been determined to a period ranging from 10400 to $5660 \mathrm{cal} \mathrm{BC}$.

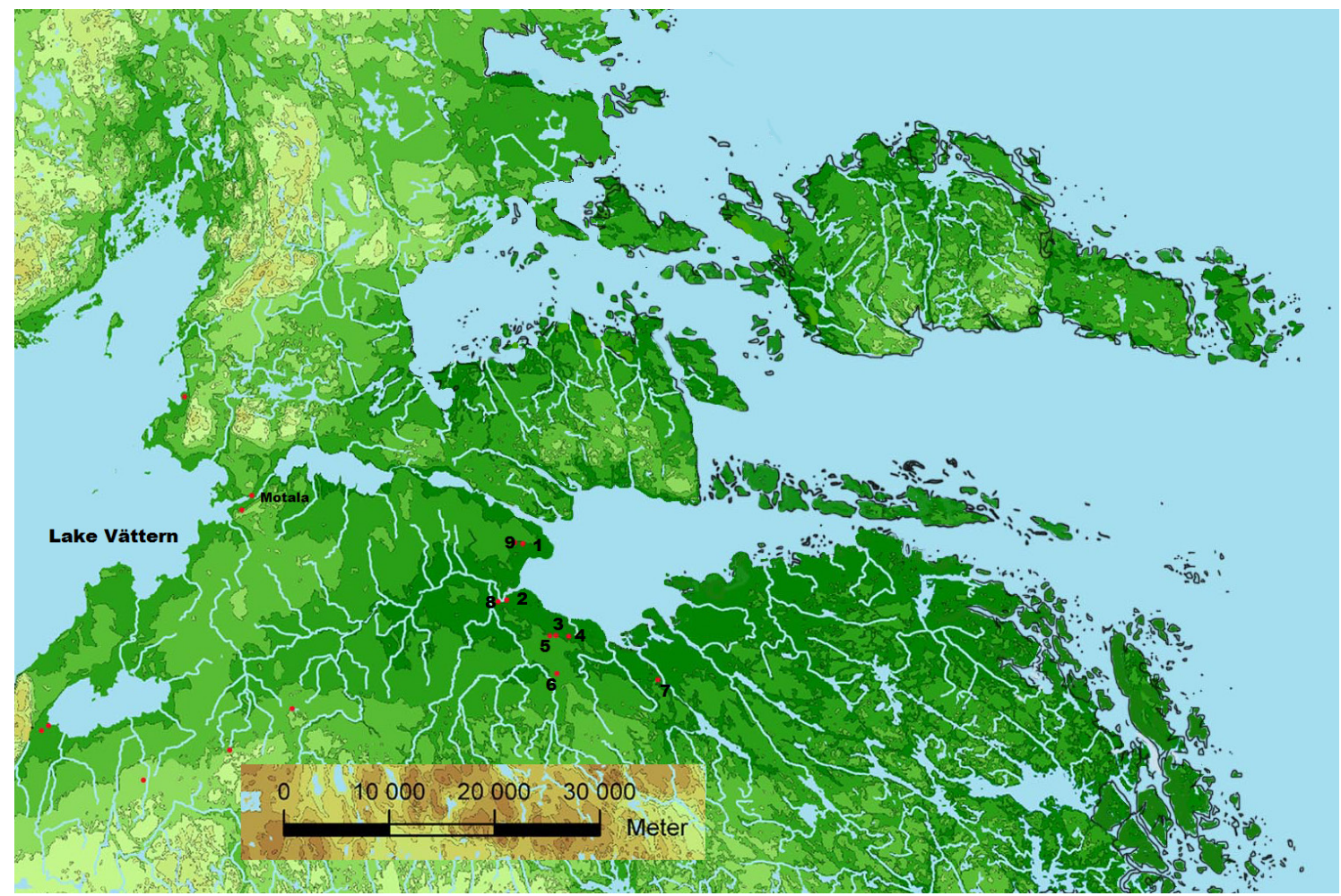

Figure 3. Map of the province of Östergötland showing the Ancylus Lake, ca $8000 \mathrm{cal} \mathrm{BC}$. Source: SGU (Swedish Geological Investigations) and sites in the text. 1) Stora Sjögestad, 2) Kränge, 3) Trädgårdstorp. 4) Intellektet), 5) Malmen, 6) Lilla Åby, 7) Harvestad, 8) Ledberg, 9) Stora Sjögestad site no 2. 


\section{Stora Sjögestad}

The settlement site was discovered in the southern slope of an east-west oriented ridge, 70-71 meters above the present sea level. There are no streams here, but the map of soil types shows that small marshy areas have occurred in the area. There are no signs today of an orientation of the settlement site towards any specific biotope or situation in the countryside [7]. Yet another Mesolithic settlement site is known in the vicinity [14]. Altogether nine radiocarbon dates were analyzed from this site. In four cases, cremated animal bones were $\mathrm{C}^{14}$-dated; the other cases were hazelnut shells and charcoal. The time range is comparatively extensive, $9359 \pm 487 \mathrm{BP}$ (Ua-29263, 10400BC (95.4\%) 7300BC) to $7540 \pm 45$ BP (GrA-53909, 6460BC (74.3\%) 6330BC). The marginal of $\mathrm{C}^{14}$-calibration, the error is wide in the earliest cases but the radiocarbon dates still tell us that the first visits to the site started during the centuries around $7500 \mathrm{cal} \mathrm{BC}$ and that visits continued for many hundreds of years onwards.

Considerable amounts of carbonized hazelnut shells were discovered in the macrofossil analysis. In the hearth situated in the house, there were burnt remains of dropwort (Filipendula vulgaris) and some form of pea (Vica). Altogether, the highly nutritious hazelnuts, peas and dropwort, most probably, were an important part of the Mesolithic diet. Recovered finds consisted mostly of lithics. Around 1400 artefacts of worked lithic were encountered, almost all placed in a pit, 20 square meters in size, situated on the western side of the house. The finds are entirely of stone: $94 \%$ were of quartz, $4 \%$ flint and $2 \%$ were of other types of rock. No flint occurs naturally in the region; the provenance of the flint can be traced to South and West Scandinavia. Micro blades and a considerable quantity of debitage from the production of micro blades dominate the finds. There is a lack of microliths throughout eastern Middle Sweden and the finds at Stora Sjögestad fit into a Mesolithic tradition of tools with attached micro blades seen in eastern Sweden [6]. Among other artefacts, two so called 'rulers' with use wear from working bone/antler were found. They were thought to have been used for carving slits when fitting micro blades into bone points [39]. The analysis of use wear indicates that the large quantity of unused micro blades is a sign of a production site. However, traces of use also imply everyday activities of a settlement site, for example, scraping and smoothing of hides, wood and bone [23]. A particular find is the deposit of 24 micro blade cores of quartz. The cores were stacked beside and on top of each other in a pit, 6-8 centimeters in size and 12-15 centimeters deep. Probably, the cores had been put in some form of bag before they were left in the pit. Around ten hammer stones, one small whetstone and two fragments of the edges of polished axes are finds supporting the interpretation that the site was used for a variety of activities [7]. All the animal bones were severely burnt and in fragments, a result is that a large proportion of the bones were unidentified. There are no traces of marine hunting or fishing, only terrestrial animals were identified. It is possible that the lack of bones from seal and fish is due to the state of fragmentation, but bones from seal are usually compact and hard; they are thus often better preserved than other bones. Consequently, in all likelihood, the lack of bones from marine animals would reflect the hunting strategies of the local community at this site (Table 1).

Table 1. Cremated bones at Stora Sjögestad. List of species and number of fragments [34]

\begin{tabular}{|c|c|}
\hline & Fragments \\
\hline Elk (Alces alces) & 1 \\
\hline Ruminant & 1 \\
\hline Pig (Sus scrofa) & 5 \\
\hline Pig? (Sus scrofa) & 3 \\
\hline Unidentified & 80 \\
\hline Total & 90 \\
\hline
\end{tabular}

Immediately to the east of the concentration of finds, some ten postholes and a hearth were discovered; these are interpreted as the traces of a building, 9.0-4.4 meters in size, oriented in an almost east-westerly direction (fig 4). The remains of the house consisted of two substantial roof-bearing central posts and ten postholes for the walls. The eastern end was rounded; the western end was straight and is considered to be the entrance. To the west, just inside the entrance, a hearth was uncovered, filled with soot/charcoal and cracked stones. A hazelnut shell in the hearth was radiocarbon dated to $7928 \pm 45$ BP (UA-29332, 7040-6660 cal BC), this most likely represents the final phase of the period when the house was used. Charcoal (Pinus) in a roof-bearing posthole and hazel (Corylus) from a posthole belonging to the wall were consequently somewhat older, 8177 \pm 47 BP (Ua-29333, 7330-7060 cal BC) and $8090 \pm 45$ BP (GrA-53910, 7310-6830 cal BC) respectively. It seems reasonable to date the house to the centuries around $7000 \mathrm{cal} \mathrm{BC}$.

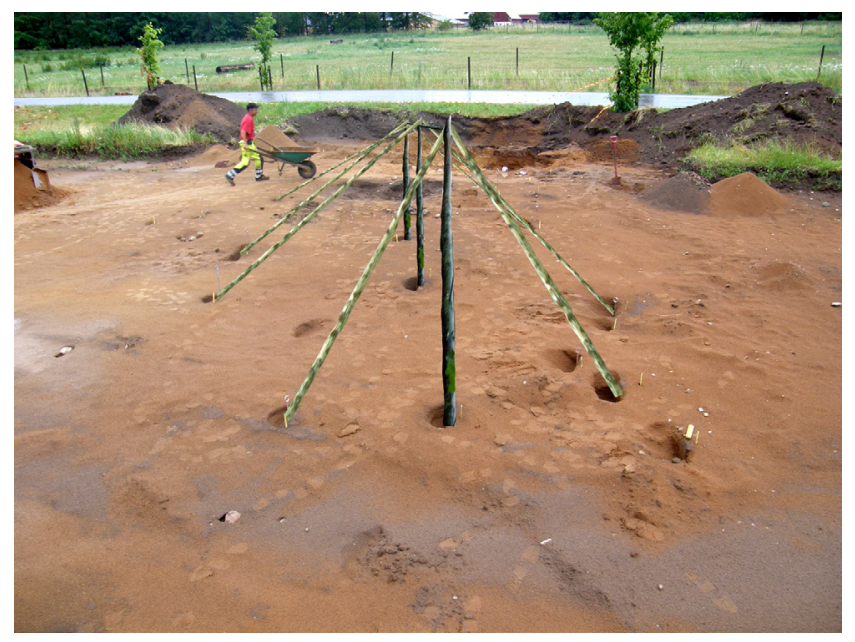

Figure 4. Image of a House. Reconstruction of the Mesolithic house at Stora Sjögestad. Photo taken from the East. Photograph Tom Carlsson. 


\section{Kränge}

The settlement site is situated less than 200 meters from River Svartån on a level of 64 meters above the sea. Concentrations of Mesolithic finds and features were uncovered within a surface of $6700 \mathrm{~m}^{2}$ at Kränge. Finds were moreover discovered in fields by the side of the rapids and meandering course of River Svartån [8]. Eight radiocarbon samples have been dated to the Mesolithic period at Kränge; these show that people used the site regularly, chiefly during two phases. The first phase was during the period of $8730 \pm 30 \mathrm{BP}$ to $8290 \pm 49 \mathrm{BP}(7800-7140 \mathrm{cal} \mathrm{BC})$, when two buildings were constructed; the second phase occurred just over a thousand years later at $6970 \pm 45 \mathrm{BP}$ to $6875 \pm 45 \mathrm{BP}$ (5930-5660 cal BC). The memory of the site must have been maintained during the period in between; perhaps the site had a use that did not leave any traces. The significance of the site can be illustrated by the fact that an early Neolithic farm was established in the same place as the Mesolithic settlement.

Approximately 9000 artefacts were recovered: $80 \%$ were of quartz, $16 \%$ of flint and the remaining $4 \%$ comprised various types of rock. The high proportion of flint is probably due to a certain inclusion of finds from later periods, for instance, an early Neolithic farm was discovered. Micro blades and micro blade cores of both quartz and flint are typical Mesolithic artefacts at Kränge. The assemblage of animal bones at Kränge is comparatively numerous (Table 2). All bones were burnt and in a state of fragmentation. A major part of the bones are therefore unidentified. Because of the Neolithic settlement at the site, it is likely that the assemblage of bones partly includes domesticated animals.

Table 2. Cremated bones at Kränge. List of species and number of fragments [41]

\begin{tabular}{|c|c|}
\hline & Fragments \\
\hline Dog (Canis familiaris) & 1 \\
\hline Elk (Alces alces) & 1 \\
\hline Roe Dear (Capreolus capreolus) & 2 \\
\hline Cervid & 3 \\
\hline Ruminant & 1 \\
\hline Large ungulate & 9 \\
\hline Large mammal & 25 \\
\hline Small ungulate & 10 \\
\hline Small mammal & 21 \\
\hline Ungulate & 1 \\
\hline Beaver (Castor fibre) & 22 \\
\hline Beaver? & 2 \\
\hline Unidentified & 3662 \\
\hline Total & 3761 \\
\hline
\end{tabular}

A particular characteristic of the site is the large quantity of artefacts and burnt bones that can be related to Mesolithic buildings. The remains of House 1 consisted of four postholes, making up a semicircular building, 2.2 meters in size, opening towards the south-west. Artefacts, debitage from the production of tools, micro blade cores and micro blades of quartz were uncovered within the semicircle. The building appears to have been a simple construction, which might have had a function as a shelter from the wind. No datable charcoal occurred in the postholes. Instead, three bones from beaver (Castor fiber), found in and immediately in front of the house, were radiocarbon dated. These bones are highly likely to originate from activities performed in the house. According to the three $\mathrm{C}^{14}$-datings, house I was used approximately in $8520 \pm 108$ BP-8267 \pm 50 BP (7480-7140 cal BC).

House II was located some ten meters further to the west. This house was $8.0 \times 3.4$ meters in size, with an east-westerly orientation. Postholes originated from two roof-bearing posts and twelve posts of the walls. Flint, quartz and burnt animal bones were concentrated within the delimitation of the house; just outside was a place for the production of micro blades. No datable organic material was to be found in these postholes either. Instead, one burnt bone (large mammal/Alces alces) from the house was used for dating. The date of House II, $8730 \pm 30$ BP (Ua-28635, 7940-7600 BC), appears to be somewhat older than House I.

\section{Trädgårdstorp}

Stone Age remains at Trädgårdstorp cover an area of more than 110000 square meters along the northern edge of a glaciofluvial deposit at about 75 meters above the present sea level. Several smaller Mesolithic settlement sites have been excavated in the area, with an earliest date of $8380 \pm 60 \mathrm{BP}$ (Ua-27495, 7580-7310 cal BC). A number of small waterways and marshes characterize the surrounding landscape. This site is judged to have been situated closer to the shore of the Ancylus Lake than Kränge and Stora Sjögestad were. The excavator concludes that the Ancylus Lake was as close as 30-40 meters from the earliest part of the settlement [29]. Nineteen radiocarbon samples from Trädgårdstorp have generated Mesolithic dates. Wood species had been determined (Pinus) in all the charcoal of the radiocarbon samples originating from postholes in houses and hearth pits close to buildings. The radiocarbon dates range over a period of almost 2000 years, $8380 \pm 60 \mathrm{BP}-$ $6940 \pm 40 \mathrm{BP}(7580-5720 \mathrm{cal} \mathrm{BC})$, indicating regular visits or more or less permanent settlement [29] 2009).

The lithic assemblage consisted of around 95\% quartz, along with some flint, porphyry and quartzite. The tools are characterized by the production of micro blades and were noticeably concentrated to the excavated remains of both buildings. Few animal bones were encountered, all bones were burnt (Table 3). Judging by the animal bones, terrestrial animals such as elk, roe deer and most likely red deer were predominant among the game. However, this site differs from the other settlement sites in the finds of seal bones and one vertebra from perch. The bones indicate a diet partially of marine food. At the same time, they show that the lack of fish and seal bones is not necessarily the result of fragmentation and difficulties in determining the species of the bones. Hazelnut shells occur in hearths and pits close to 
both houses as well.

Table 3. Cremated bones at Trädgårdstorp. List of species and number of fragments [40]

\begin{tabular}{|c|c|}
\hline & Fragments \\
\hline Elk (Alces alces) & 14 \\
\hline Roe Dear (Capreolus capreolus) & 1 \\
\hline Cervid & 2 \\
\hline Seal (Phocidae) & 1 \\
\hline Perch (Percidae) & 1 \\
\hline Unidentified & 86 \\
\hline Total & 105 \\
\hline
\end{tabular}

The remains of two houses were discovered in Trädgårdstorp. Within two areas, two marked concentrations of finds were noted, along with pits and hearths filled with cracked stones, soot, charcoal and hazelnut shells. Worked stone and bones were also noticeably concentrated to this area. Several postholes were discovered belonging to two buildings; in shape and size, they were alike as if from a blueprint [31]. The houses were around $6.7 \times 4.5$ meters in size, oriented in a north-south direction. They had rounded ends and the entrances probably faced north. The houses were held up by one, perhaps two, roof-bearing posts, with around 10 posts along the walls. Indoors, there was a thin cultural layer where most of the finds were recovered. In house II, there is a clear spatial division of where the different raw materials were worked. Flint occurred almost only in the southern part of the house, while quartz was predominant to the north, nearest the entrance. Furthermore, analysis of the chemical properties of the soil indicates a wall-effect, with an increase in levels of phosphates alongside the posts of the wall. House I is dated within the range of 7050-6340 cal $\mathrm{BC}$, with a probable age towards the end of the period. House II is several hundred years older, 7580-7350 cal BC.

Table 4. Sites: meters above sea, findings and ${ }^{14} \mathrm{C}$-datings

\begin{tabular}{|c|c|c|c|c|c|c|c|c|}
\hline Site & $\begin{array}{l}\mathrm{M} \\
\text { a s }\end{array}$ & Features & Charcoal & $\begin{array}{l}\text { Bones: } \\
\text { classified }\end{array}$ & Macrofossils & Artefacts & $\begin{array}{l}{ }^{14} \mathrm{C}, \\
\text { Numbers }\end{array}$ & Dates, range \\
\hline Harvestad & 82 & $\begin{array}{l}\text { Hearts, } \\
\text { pits }\end{array}$ & Pine & - & Hazelnut shells & $\begin{array}{l}\text { Quarts, tools and } \\
\text { splinters }\end{array}$ & 3 & $\begin{array}{l}8192 \pm 49- \\
7959 \pm 52 \mathrm{BP}\end{array}$ \\
\hline Intellektet & 70 & $\begin{array}{l}\text { Hearts, } \\
\text { pits, } \\
\text { house }\end{array}$ & Pine & - & Hazelnut shells & $\begin{array}{l}\text { Quartz and flint - } \\
\text { cores, tools and } \\
\text { splinters }\end{array}$ & 4 & $\begin{array}{l}8175 \pm 60- \\
7860 \pm 55 \mathrm{BP}\end{array}$ \\
\hline Trädgårdstorp & 75 & $\begin{array}{l}2 \text { houses, } \\
\text { post holes, } \\
\text { pits, } \\
\text { hearths }\end{array}$ & Pine & $\begin{array}{l}\text { Elk, Roe } \\
\text { deer, Seal, } \\
\text { perch }\end{array}$ & Hazelnut shells & $\begin{array}{l}\text { Quartz and flint - } \\
\text { cores, tools and } \\
\text { splinters }\end{array}$ & 22 & $\begin{array}{l}8380 \pm 60- \\
6940 \pm 40 \mathrm{BP}\end{array}$ \\
\hline Kränge & 64 & $\begin{array}{l}2 \text { houses, } \\
\text { Post } \\
\text { holes, } \\
\text { pits, } \\
\text { hearts }\end{array}$ & Pine & $\begin{array}{l}\text { Dog, Elk, } \\
\text { Roe deer, } \\
\text { Dear, } \\
\text { Beaver }\end{array}$ & Hazelnut shells & $\begin{array}{l}\text { Quartz and flint - } \\
\text { cores, tools and } \\
\text { splinters, ax head }\end{array}$ & 8 & $\begin{array}{l}8730 \pm 30- \\
6875 \pm 45 \mathrm{BP}\end{array}$ \\
\hline Ledberg & 75 & Hearth & Pine & - & - & $\begin{array}{l}\text { Quarts, core and } \\
\text { splinters }\end{array}$ & 1 & $7060 \pm 40 \mathrm{BP}$ \\
\hline Lilla Åby & 85 & $\begin{array}{l}\text { Hearts, } \\
\text { pits }\end{array}$ & $?$ & - & - & $\begin{array}{l}\text { Quarts, cores, } \\
\text { tools and splinters, } \\
\text { flint arrow head }\end{array}$ & 10 & $\begin{array}{l}8920 \pm 130 \\
-8440 \pm 130 \mathrm{BP}\end{array}$ \\
\hline Malmen & 87 & $\begin{array}{l}2 \text { Houses, } \\
\text { pits, } \\
\text { hearths }\end{array}$ & Pine & - & - & $\begin{array}{l}\text { Quarts, cores, } \\
\text { tools and splinters }\end{array}$ & 1 & $7640 \pm 30 \mathrm{BP}$ \\
\hline $\begin{array}{l}\text { Stora } \\
\text { Sjögestad }\end{array}$ & 71 & $\begin{array}{l}1 \text { House, } \\
\text { hearth, } \\
\text { pits }\end{array}$ & $\begin{array}{l}\text { Pine, } \\
\text { willow, } \\
\text { hazel, } \\
\text { juniper }\end{array}$ & Elk, pig & $\begin{array}{l}\text { Hazelnut shells, } \\
\text { dropwort, pea }\end{array}$ & $\begin{array}{l}\text { Quartz and flint - } \\
\text { cores, tools and } \\
\text { splinters, ax head }\end{array}$ & 9 & $\begin{array}{l}9359 \pm 487- \\
7540 \pm 45 \text { BP }\end{array}$ \\
\hline Universitetet & 70 & Hearths & Pine & - & & $\begin{array}{l}\text { Quarts, tools and } \\
\text { splinters }\end{array}$ & 2 & $\begin{array}{l}8300 \pm 65- \\
7570 \pm 70 \mathrm{BP}\end{array}$ \\
\hline $\begin{array}{l}\text { Stora } \\
\text { Sjögestad, site } \\
\text { no } 2\end{array}$ & 75 & Hearth & $?$ & - & - & Quartz splinter & 1 & $8150 \pm-90$ BP \\
\hline
\end{tabular}




\section{Intellekted, Åby, Harvestad and Other Sites}

Currently, a further seven Mesolithic settlement sites are known, in various states of preservation (Table 4). Many times, Mesolithic remains are encountered together with remains from later periods; various excavation methods and different focus might therefore have been employed. At the Intellektet site, a round dwelling with a sunken floor was discovered. The house was $4.8 \times 4.4$ meters in size; analysis of four radiocarbon samples resulted in a dating to 8175 7860 BP (7350-6590 cal BC). Unfortunately, no animal bones were found; the recovered finds consisted only of cores and tools of quartz [30]. During the summer of 2015, remains of yet another Mesolithic house were discovered at Malmen, dated to $7640 \pm 30$ BP (ICA ID $15 \mathrm{C} / 0807$, $6568-6435 \mathrm{cal} \mathrm{BC)} \mathrm{[48].} \mathrm{The} \mathrm{house} \mathrm{was} \mathrm{similar} \mathrm{to} \mathrm{those} \mathrm{at}$ Trädgårdstorp. Ten radiocarbon samples resulted in dates within the range of 8550-7550 cal BC at Lilla Åby. No traces of buildings were recorded and only a small lithic assemblage was recovered [1]. The settlement site at Harvestad was dated to 8192-7959 cal BC, containing a small assemblage of flint, quartz and burnt animal bones (unidentified) [12]. Other Mesolithic sites in the vicinity occur at Linköpings universitet [33], Ledberg [38] and site no 2 at Stora Sjögestad [14].

\section{Places for the Presence of the Past, Memories - Discussion}

In the introduction the question about predictive mobility was raised. In this present day, does the idea of mobility between small inland sites and large coastal settlements still work as a general model for interpretation? Today, when a greater number of strontium and other isotope analyses on human remains are performed throughout Europe we can see the indications that Mesolithic societies had considerably more varied and complex economic strategies than any archaeological model could have predicted. There is a difference in diet between local communities, different age groups, as well as between individuals [13, 16, 36, 15, 26].

In the light of laboratory archaeology we can suggest several different ways that hunters-gatherers organized their living, even for the sites where we cannot do analyzes of isotopes, other than ${ }^{14} \mathrm{C}$-datings. In a study of animal bones and macrofossils at Neolithic settlement, sites in central Sweden, Fredrik Hallgren [18] distinguishes between land-oriented and shore-oriented settlement sites. A similar analysis of the Mesolithic settlement sites presented here would identify them as land-oriented. Regarding the composition of animal bones, we see that elk, red deer, roe deer and beaver were hunted and hazelnuts were gathered in the forest, and that this was preferred rather than establishing new settlements at the disappearing shores to fish and hunt seal in the Ancylus Lake. Since no human skeletons or scattered human bones has been found and, so far I know, it is not possible to perform Isotope analysis on burnt organic material no additional analysis has been made. Therefore it is possible that isotope analyses of human bones would reveal a different intake of proteins than we can conclude only from the remaining animal bones. So even if they did use the sea for fishing-hunting they still reused the same settlement sites. According to economy and continuity, the sites presented in this paper does not fit into the traditional economical model of coastal - inland mobility. Instead we need a perception of landscape and places. In my view, concepts such as memory and experience in conjunction with an active notion of spatiality can broaden our view of humans, identity and landscape. Everyday activities, hunting, gathering walking, collecting firewood and so on, created these memories and the meaningfulness to the landscape. People created special relationships with places, which were meaningful in a way beyond economy. In Heidegger's concept of dwelling [19], relationships with certain places were created through intentional and lasting changes of the place.

Memories is not, of course, a contradiction to mobility. Therefore, an important part of the study is that we can follow the establishment of settlement sites in the landscape, in a certain environment, but we also see that settlement continues at the same places even throughout the substantial changes of the landscape involved in the elevation of the land. A social group (I. e. a local community) might have utilized places or an area in many different ways depending on several factors. In a time-perspective of a few hundred years, settlement patterns involving temporary visits as well as permanent living may evolve [25]. People where connected to places. Once people had established these economical/social relations to places, even in a changing environment, we can see that peopled kept that relationship by using the places for every-day activities over and over again. For a very long time. If mobility occurred from coast to inland at least it was not a settlement pattern. It's my opinion that mobility is no essence for Mesolithic living and Mobility therefore can be questioned as a general model. Houses are perhaps the clearest manifestation of the physical socialization of a place; it becomes the place for something, for somebody. The sites stand out as something more than focal points, just for subsistence, rather as places for 'the presence of the past, memories' [19] In this sense the landscape where the Mesolithic people moved around should not be regarded as a marked out territory, but as various places for activities, for events or memories of earlier events. Paths, a forest glade, lakes, streams and mountains are places too. Knowledge of physical places, the settlement sites of other local communities, occurrence of flint, greenstone and quartz, places for fishing and hunting, rich copses of hazel, all were interwoven along with memories and stories from past times. Analyses of macrofossils and pollen in bogs reveal a prehistoric landscape interspersed with many shallow lakes, wetlands and waterways. The ecological environment of inland settlement sites offered economic 
conditions very similar to Trädgårdstorp, Kränge, Stora Sjögestad and the other settlement sites shortly presented in my paper. This type of forest was favorable for red deer, roe deer, wild boar, but an even more important economic factor was the prevalence of hazel (Corylus). Hazelnut shells are found at almost every Mesolithic settlement site in southern Scandinavia; nuts were probably the most important source of nourishment during a major part of the year [21,35]. Animal bones found at inland settlement sites also indicate that red deer, elk and beaver were hunted, along with the gathering of hazelnuts. In conclusion, if the purpose of mobility was to maximize the use of resources in different ecological niches, the general model of mobility, i.e. small groups moving seasonally between inland and coast falls. At least it does not seem to be a relevant overall model, and the essence of Mesolithic life.

To conclude: does the idea of mobility between small inland sites and large coastal settlements still work as a general model for interpretation? Laboratory archeology has proven that predictive modeling of Mesolithic mobility, from large coastal settlements during winter and small inland summer sites is simplified. Settlement patterns can appear in so many different ways. Human societies are not that one-dimensional and predictable because of the hunter-gatherer economy. My answer to the question of mobility is that we need to question every axiom. Was mobility the essence of life for Mesolithic hunter-gatherers? And doing so, we need to replace this supposed essence of life with more complex and variated interpretations.

\section{Acknowledgements}

This paper was enabled by generous funding from the Westman-Wernerska foundation, Linköping and the Claes and Greta Lagerfelt's foundation, Linköping, both In the Östergötland province Sweden.

Thanks to Fredrik Molin for giving valuable insights and information.

Translated by Judith Crawford

judith.crawford@glocalnet.net

\section{REFERENCES}

[1] Appelgren, K. 1995. Lilla Aby. Arkeologisk undersökning. Rapport UV Linköping 1995:19. Linköping.

[2] Bergson, H. 1998 (1911). Creative evolution. Dover books. www.doverpublications.com

[3] Binford, L-R. 1980. Willow smoke and dogs' tails: hunters and gatherer settlement systems and archaeological site formation. In: American Antiquity 45.

[4] Bonnet, A. 2000. "Alternative" Film or "Other" Film? In and Against the West with Trinh Minh-Ha. In: Thinking space. (Crang, M \& Thrift, $\mathrm{N}$ eds). London.
[5] Carlsson, T. 2007. Mesolitiska möten. Strandvägen en senmesolitisk boplats vid Motala ström. Acta Archaeologica Lundensia. Series prima in 80, No 54.

[6] Carlsson, T. 2008. Where the river bends. Under the boughs of trees. Acta Archaeologica Lundensia. Series prima in $8^{0}$, No 55. Riksantikvarieämbetet UV Skrifter.

[7] Carlsson, T. 2012. Mesolitikum och bronsålder $i$ Stora Sjögestad. Arkeologisk förundersökning och särskild undersökning inom RAÄ 232 i samband med planerad ombyggnad av väg till Vreta naturbruksgymnasium. Vreta kloster socken, Linköpings kommun, Östergötland. Rapport Riksantikvarieämbetet, UV Öst 2012:68.

[8] Carlsson, T. 2014a. Stenåldersboplatser och medeltida skelettbegravningar $i$ Kränge. Östergötland, Linköpings kommun, Ledbergs socken, Ledbergs-Tomta 3:2, RAÄ 41. UV rapport 2014:56.

[9] Carlsson, T. 2014b. This must be the place. Perspectives on the Mesolitic - Neolitithic transition in Östergötland, Eastern Middle Sweden. Riksantikvarieämbetet \& Oxbow books.

[10] Carlsson, T.. Gruber, G.. \& Molin, F. 2005. The Mesolithic in Östergötland - An introduction. In: Identities in Transition. Mesolithic strategies in the Swedish province of Östergötland (Gruber, G. ed.). Riksantikvarieämbetets Arkeologiska undersökningar. Skrifter no 64.

[11] Crang, M. \& Thrift, N. 2000. Thinking space. London.

[12] Ericsson, A. \& Stenvall, J. 2013. Harvestad - en by $i$ eklandskapet. Arkeologisk för- och slutundersökningar. Östergötland. Linköpings kommun. Landeryds socken. RÄ̈ $309,312,359,375,376,377,378,379,380,381$. Riksantikvarieämbetet, UV Rapport 2013:113.

[13] Eriksson, G., Margarita Frei K., Howcroft, R., Gummesson, S., Molin, F., Lidén, K., Frei, R. and Hallgren, F. 2016. Diet and mobility among Mesolithic hunter-gatherers in Motala (Sweden) - The isotope perspective. In: Journal of Archaeological Science: Reports 3 june 2016.

[14] Fernholm, R. 1983. Ett flatmarksgravfält från yngre bronsåldern. Fornlämning 86, Stora Sjögestad, Vreta klosters socken, Östergötland. Riksantikvarieämbetet och Statens historiska museer Rapport UV 1982:44.

[15] Fischer, A., Olsen, J., Richards, M., Heinemeier, J., Sveinbjörnsdóttir Á. E., Bennike, P. 2007. Coast-inland mobility and diet in the Danish Mesolithic and Neolithic: evidence from stable isotope values of humans and dogs. In: Journal of Archaeological Science 34(12): December 2017.

[16] Guiry, E.J., Hillier, M., Richards, M.P. 2015.Mesolithic Dietary Heterogeneity on the European Atlantic Coastline. Stable Isotope Insights into Hunter-Gatherer Diet and Subsistence in the Sado Valley, Portugal. In: Current Anthropology Volume 56, Number 3, June 2015.

[17] Halbwach, M. 1980 (1950). The Collective Memory. New York.

[18] Hallgren, F. 2008. Identitet i praktik. Lokala, regionala och överregionala sociala sammanhang inom nordlig trattbägarkultur. Coast to coast-books 17. phD dissertation. Uppsala University.

[19] Heidegger, M. 1977. Building dwelling thinking. In: Krell, D. F. (ed) Martin Heidegger: Basic writing. London. 
[20] Kaliff, A., Carlsson T., Molin, F. \& Sundberg, K. 1997. Mörby. Östergötlands äldsta boplats. Riksantikvarieämbetet. Avdelningen för arkeologiska undersökningar. Rapport UV Linköping 1997:38. Linköping.

[21] Karsten, P. \& Knarrström, B. 2003. The Tågerup Excavation. Skånska spår - arkeologi längs västkustbanan. Riksantikvarieämbetet, UV Syd. Trelleborg.

[22] Knutsson, H. 1995. Slutvandrat? Socetitas Archaeologica Uppsalaiensis. Thesis and papers, AUN 20. Uppsala.

[23] Knutsson, H. 2012. Rapport från analys av stenmaterialet från RA Ä 238, Vreta kloste sn Östergötland. In: Carlsson, T. 2012. Mesolitikum och bronsålder $i$ Stora Sjögestad. Arkeologisk förundersökning och särskild undersökning inom RAÄ 232 i samband med planerad ombyggnad av väg till Vreta naturbruksgymnasium. Vreta kloster socken, Linköpings kommun, Östergötland. Rapport Riksantikvarieämbetet, UV Öst 2012:68. Linköping.

[24] Larsson, L. 1995. Man and sea in Southern Scandinavia during the Late Mesolithic. The role of cementries in the view of society. In: Man and Sea In the Mesolithic. Coastal settlements above and below present sea level. (Fischer, A. ed.). Proceeding of the International Symposium, Karulund, Denmark 1993. Oxford.

[25] Larsson, L. 2005. From blank spot to focal point. An eastern Swedish site from a south Scandinavian perspective. In: Identities in Transition. Mesolithic strategies in the Swedish province of Östergötland. (Gruber, G. ed.). Riksantikvarieämbetets Arkeologiska undersökningar. Skrifter no 64. Linköping.

[26] Lidén, K., Eriksson, G., Nordqvist, B., Göteström, A. and Bendixen, E. 2004. The wet and wild followed by the dry and tame - or did they occur at the same time? Diet in Mesolithic - Neolithic southern Sweden. In: Antiquity, volume 78 Issue 299. March 2004.

[27] Lee, R. B. \& De Vore, I. 1968. Man the Hunter. Chicago.

[28] Molin, F. 2000. Mesolitikum i västra Östergötland forskningsläge och aktuella problemområden. I: Vetenskaplig verksamhetsplan för UV Öst, arkeologiskt program 2000 2002. Riksantikvarieämbetet, Arkeologiska undersökningar. Rapport UV Öst 2000:21. Stockholm.

[29] Molin, F. 2007a. Äldre stenålder i Jägarvallen. Arkeologisk förundersökning. Riksantikvarieämbetet. UV Öst Rapport 2007:10. Linköping.

[30] Molin, F. 2007b. Mesolitisk hyddlämning vid Kv Intellektet. Arkeologisk undersökning med anledning av nya studentbostäder inom Valla koloniområde RAÄ 421. Kv Intellektet 5 Linköpings stad och kommun. Östergötland. Uv Öst Rapport 2007:56.

[31] Molin, F. 2009. Along the shore of the Ancylus Lake. Trädgårdstorp and the other coastal Mesolithic settlement sites during the Late Ancylus period in Western Östergötland. In: Mesolithic Horizons. Papers presented at the Seventh International Conference on the Mesolithic Europe, Belfast 2005 (McCartan, S.B., Schulting, R., Warren, G. \& Woodman, P. eds).

[32] Molin, F. \& Larsson, M. 1999. Mesolitikum vid Storlyckanhyddlämning och fyndmaterial. Riksantikvarieämbetet, Arkeologiska undersökningar. Rapport UV Öst. 1999:1.
Linköping.

[33] Molin, F. \& Molin, A. 2004. Linköpings universitet boplatser och gravfält. Arkeologisk utredning av tre områden inom norra delen av universitetsområdet. Linköpings universitet, Intellektet 1, Linköpings stad och kommun, Östergötland. Riksantikvarieämbetet UV Öst Rapport 2004:11.

[34] Olson, C. 2012. Osteologisk undersökning av ben från St. Sjögestad, Vreta Kloster Socken, Östergötland, RAÄ 232. In: Carlsson, T. 2012. Mesolitikum och bronsålder $i$ Stora Sjögestad. Arkeologisk förundersökning och särskild undersökning inom RAÄ 232 i samband med planerad ombyggnad av väg till Vreta naturbruksgymnasium. Vreta kloster socken, Linköpings kommun, Östergötland. Rapport Riksantikvarieämbetet, UV Öst 2012:68.

[35] Regnell, M. 2012. Plant subsistence and environment at the Mesolithic site Tågerup, southern Sweden: new insight on the "Nut Age". In: Vegetation history and archaeobotany (2012) 21.

[36] Schulting, R. 2010. Staying home for dinner: an isotopic approach to regionality in Mesolithic Atlantic Europe. In: The Archaeology Of Regional Technologies. Case Studies from the Palaeolithic to the Age of the Vikings. (Barndon. R., Engevik, A \& I. Øye, I. eds.) The Edwin Mellen Press.

[37] Shurmer-Smith, P. 2000. Hèléne Cisous. IN: Thinking space. (Crang, M. \& Thrift, N. eds.). London.

[38] Sjölin, M. 2011. Boplatslämningar $i$ Ledbergs-Tomta. Arkeologisk förundersökning. Fastigheten Ledbergs-Tomta 4:1 Inför planerad villabebyggelse, RAÄ 43, Ledbergs socken, Linköpings kommun, Östergötland. Riksantikvarieämbetet UV rapport 2011:116.

[39] Sjöström, A. \& Nilsson, B. 2009. "Rulers" of the southern Scandinavia: technological aspects of a rediscoverd tool. In: Mesolithic Horizons. (McCartan, S.B., Schulting, R., Warren, G., \& Woodman, P. eds). Papers presented at the Seventh International Conferece on the Mesolithic Europe, Belfast 2005. Oxbow, Oxford.

[40] Storå, J. 2007. Osteologisk analys av ben från Jägarvallen, Kärna socken, Linköpings kommun, Östergötland. In: Molin, F. 2007. Äldre stenålder $i$ Jägarvallen. Arkeologisk förundersökning. Riksantikvarieämbetet. UV Öst Rapport 2007:10. Linköping.

[41] Storå, J. 2014. Osteologisk analys av ett bränt skelettmaterial från Kränge i Ledbergs socken. Ledberg-Tomta 3:2 RÄ̈ 41. Östergötland. In: Carlsson, T. 2014. Mesolitiska boplatser och medeltida gravar i Ledberg, Kränge. Ledbergs socken, Linköpings kommun, Östergötland. Riksantikvarieämbetet, UV Öst Rapport.

[42] Strassbourg, J. 2005. Rituals at the Meso 2000 Conference and the Mesolithic-Neolithic Terminolocial Breakdown. In: Mesolithic on the Move. Papers presented at the Sixth International Conference on the Mesolithic in Europe, Stockholm 2000. Larsson, L. Kindgren, H., Knutsson, K., Loeffler, D. \& Åkerlund, A. eds). Oxford.

[43] Sundström, L. 2003. A Collective in Peril. In: Coast to Coast. Arrival. Results and Reflections. Proceding the Final Coast to Coast Conference 1-5 October 2002 in Falköping, Sweden (Knutsson, H. red.) Uppsala.

[44] Sutton, D. 2011. Memory as a sense: a Gustemological 
Approach. In: Food culture \& society Volume 14. Issue 4

[45] Thomas, J. 1993. The hermeneutics of Megalithic space. In: Interpretative Archaeology, (Tilley, C. ed.). Oxford.

[46] Thomas, J. 2004. Archaeology and Modernity. London \& New York.

[47] Wickham-Jones C. 2005. "Summer walkers? - Mobility and the Mesolithic". In: Mesolithic Studies at the Beginning of the 21st Century (Milner, N. \& Woodman P. eds.) Oxford.

[48] Westeberg, A. 2016. En Mesolitisk boplats samt utmarksaktiviteter under yngre järnålder på Malmens flygplats. Rapport 2016:9. Arkeologisk förundersökning. Kärna 148:1. Kärna socken, Linköpings kommun. Östergötland. 